\title{
Gilbert Keith Chesterton - A Leftist
}

\section{Maciej Sobiech* \\ University of Silesia, Poland}

*Corresponding author: Maciej Sobiech R, University of Silesia, Poland, Tel: +48604441533; Email: maciej.piotr.sobiech@interia.pl

\section{Research Article}

Volume 4 Issue 2

Received Date: April 06, 2021

Published Date: May 10, 2021

DOI: $10.23880 /$ phij-16000175

\section{Abstract}

The aim of this paper is to present Gilbert Keith Chesterton as, politically, man of the Left rather than Right - and thus at least open a debate about the possible re-interpretation of his political heritage as a publicist. Firstly, the subject is generally introduced, with the characteristically "rightist" tendencies of chestertonology (and one votum separatum) outlined. Secondly, the right wing-left wing differentiation is briefly explained, basing on Letter on Independence by Jacques Maritain. Thirdly, Chesterton's political writings are examined according to the logical structure provided by the Letter... that is: in reference to personal temperament, general political ideas and the practical elements of political program, with the attempt of demonstrating that Chesterton, in all these three areas, displayed a distinct leaning towards the Left, with even the most right-winged elements of his political ideas being interpreted by him, in fact, in a "leftist" context. The text ends with a set of more practical conclusions, concerned chiefly with the future of chestertonological research.

Keywords: Gilbert Keith Chesterton; The Right; The Left; Jacques Maritain; Distributism; Letter on Independence; Originality; Rousseauism

Even though the thought and heritage of Gilbert Keith Chesterton in general, and his political thought in particular, have recently been the subjects of a quite considerable revival of interest, including the academic interest, yet it might be argued that, at least from the point of view of the object, its proper character and individual exigencies, the situation is still far from ideal - for the revival in question, admirable as it is, seems to be suffering, in my opinion at least, from a certain polarization, certain one-sidedness, that, being ideological in nature, prevents the proper hermeneutics of Chesterton's writings and intellectual creation, and his personality as well, to come into full formation. Politics, incidentally, provides the most telling examples of this state of things, as it seems quite improbable that so little attention has been paid to Chesterton's connections with the so-called "political Left". The aim of the paper is to provide at least a makeshift remedy this unquestionable deficiency and if not anything else than just to indicate several new paths alongside which this exceedingly deep and complex thought might be explored and understood.

That Chesterton has generally been considered a man of the political "Right" is, one might suppose, a question of common sense. And the word "sense" plays here a very important role. One might doubt whether any chestertonologist ever called this writer a "Rightist" or identified him like so in any more open way - at least I do not remember any such instance. But it is a question of precisely of a certain feeling, a certain moral atmosphere in which the major bulk of chestertonological studies are now conducted that decides the case quite unmistakably. This fact has, moreover, already been indicated by a certain reader of Chesterton's books, one Matthew Huntbach, who in his letter to the editor of The Chesterton Review, printed in the 3 issue 


\section{Philosophy International Journal}

for the year 1992, wrote:

I do find in the Chesterton Review a worrying tendency for contributors to over-emphasise those of Chesterton's views which can be fitted in to the conventional political "right" and to under-emphasise those which can be fitted into the conventional political "left". In particular, Chesterton's views on sexual morality are covered too prominently, and those on economic morality given not nearly enough prominence. The usual pattern is for a sustained conservative blast, with a little liberal whimper patched on as an afterthought. This tendency has been such that I have at times considered cancelling my subscription to the Society on the grounds that it is just too partisan in its view of what Chesterton was and in its view of his relevance to modem times ${ }^{1}$.

The letter was left unanswered, which only adds force to the argument presented here, which - let it be added - is excellently phrased and manages to reach the essence of the thing: it is not as much by the manner of open declarations, but rather of the manner of presentation, style, of what is included in and what is left aside (choice of subjects, the contexts in which they are elaborated upon) that the "orthodox" - "rightist" chestertonological discourse operates and finds its footing. And indeed, a glance through, say, a little (and in its own kind very valuable) book such as The Hound of Distributism (2015) issued by The American Chesterton Society quite suffices to grasp the meaning of this. It consists, to phrase it succinctly, solely of the "traditional" chestertonological subjects. There is, for example, an article by David W. Cooney on the principle of subsidiarity ${ }^{2}$ or by Philip Maxence on the connection of Chesterton's economic ideas to the notion of the common good ${ }^{3}$ - both subjects directly and explicitly pertaining (which the authors admit openly) to the traditional Catholic Social Teaching and the moral theology of Thomas Aquinas, so traditionally associated with the political "right." ${ }^{4}$ In yet another text, one by William E. Fahey, Chesterton's ideas are connected explicitly with the ideals of "monarchy and aristocracy," with a distinctly antidemocratic touch to the whole manner in which the problem

1 Matthew Huntbach, "Chesterton and the Political Left," The Chesterton Review, Vol. 18, No. 3 (1992), pp. 464-465.

2 David W. Cooney, "Understanding subsidiarity" in: ed. Richard Aleman, The Hound of Distributism (Charlotte: ACS Books, 2015), p. 81

3 Philip Maxence, "Distributism, the Common Good and the rejection of Totalitarianism" in: The Hound of Distributism, p. 123, 128-129 et al.

4 Jacek Bartyzel, Prawica-nacjonalizm-monarchizm (Warszawa: Wydawnictwo Von Borowiecky, 2016), p. 36. is presented..$^{5}$ And, just to end this brief enumeration with force, if we dig a little deeper, we can find "flowers" such as that by the pen of one Philip Blond, who - in connection with something completely different - openly urges to reject libertarianism on the ground that it is... "leftist." Such and similar examples are simply innumerable and all add to the statement we are trying here to make; and, to make a long story very, very short, there are indeed no "leftist" subjects analyzed.

And, to end our enumeration here, the result is of course such that the image of "Chesterton the rightist" penetrates to the public view, where - in the immortal words of Jacques Maritain from his Letter on Independence (1935) passing through "the opinions of men, the evil commerce of appearance and blood, the terrors and hatreds"7 it becomes a parody of itself - but a telling parody indeed; and let us say here for the moment only as much as that it is emphatically not an accident that Adam Gopnik, in his famous article from The New Yorker, published when the first talks about the possibilities of Chesterton being beatified commenced, called this author "a medievalising reactionary [who] dreamed of an anti-capitalist agricultural state overseen by the Catholic Church and governed by a military" ${ }^{\text {. }}$. William Oddie, to whom I owe this information, is quite right in calling these accusations "grotesque" - but it is all the more suggestive that he is able to to this, and to repel them almost effortlessly, because he himself is one of the pioneering researchers that acknowledge the "leftist" leaning in Chesterton's political attitude (suffice to recall here some of the many magnificent passages from his Romance of Orthodoxy [2008] treating about Chesterton's revolutionary sympathies, republicanism, democratism - and even pro-socialist tendencies of his youth ${ }^{10}$ ) - and it is in a monograph edited by himself that an excellent article by Sheridan Gilley "Chesterton: the Journalist as Saint" was published that explores many unbeaten pathways in the direction we are looking towards. "[His] enthusiasm for red revolution," writes Gilley in one of my favorite chestertonological passages ever penned, "should give the lie to the absurd assertion that Chesterton was some

5 William E. Fahey, "Towards a Description of Distributism" in The Hound of Distributism, p. 26.

6 Philip Blond, "The Participative Economy" in: The Hound of Distributism, p. 121.

7 Jacques Maritain, Letter on Independence, trans. Otto Bird in: ed. Otto Bird, The Collected Works of Jacques Maritain, Vol. XI (Notre Dame: University of Notre Dame Press, 2012), p. 123.

8 After: William Oddie, "The Philosemitism of Gilbert Keith Chesterton" in: ed. William Oddie, The Holiness of Gilbert Keith Chesterton (Leominster: Gracewing, 2010), pp. 124-125.

9 Ibid., p. 124.

10 William Oddie, Chesterton and the Romance of Orthodoxy (Oxford: Oxford University Press, 2010), pp. 79, 97-98, 198. 


\section{Philosophy International Journal}

sort of fascist. He was an anti-elitist, a populist, a democrat heart and soul"11. In other words: he was a left-minded, and certainly a left-hearted political thinker and publicist. And so it seems that Mr. Huntbach was absolutely right: for without this perspective it is indeed quite impossible to understand neither "what Chesterton was" nor "his relevance to modern times."

What does it mean, however, to be a "leftist" or (as we most probably should have dropped this rather degrading term a long time ago) a person of the left? It is in itself very, very difficult to define - and as such perhaps forms a part of the problem. Przemysław Maj, in his recent treatise upon the subject, demonstrates for example how problematic and difficult to grasp is the very left-center-right triad upon which quite obviously such predicates are logically dependent - especially if one delves into the ocean of the concrete and the particular, with the political scientists using a variety of formulae and graphs in order to classify the mass of the political parties, societies and movements that exist or existed upon the face of the earth ${ }^{12}$. It is, simply, a chaos in which boundaries become blurred, notions overlap, and many thins can be defined as either politically left or politically right depending on the point of view. No doubt, then, that many chestertonologists should fail to notice Chesterton's left-wing tendencies, considering that it is quite unclear of how they are to determine what they are. However, it is (I am sad to say) as much due to the immanent complexities of the object as to the general mental confusion of the minds which attempt to deal with it - which is the result of the fact that a large bulk of the supposedly "academic" analysis is in itself bound up in the ideological "right vs. left" conflict. A Polish-American scholar Jan Marek Chodakiewicz, for example, in his book devoted to differentiating the right wing of the political scene from the left does not hesitate to use associative and openly ideological argument only because it serves his political purpose ("the phrase 'the left' is usually associated with inefficiency, illegality or dishonesty, e.g. 'having two left hands'"13). It is, of course, just one instance out of many. And our statement is confirmed all the more by if we observe that if the question be examined from a proper perspective, supported by the light of true philosophy, all the confusion disappears and a both simpler and more fruitful discourse becomes a possibility. And this, in turn, can be proven on the basis of a text that we have already made use here - Jacques Maritain included a short analysis of the problem in his Letter on Independence and it is from this

11 Sheridan Gilley, "Chesterton: Journalist as Saint" in: The Holiness of Gilbert Keith Chesterton, p. 121.

12 Przemysław Maj, Lewicowość, centrowośc i prawicowość (Rzeszów: Wydawnictwo Uniwersytetu Rzeszowskiego, 2018), pp. 15-21, 24-27 etc.

13 Jan Marek Chodakiewicz, 0 prawicy i lewicy (Warszawa-Gdańsk: Biblioteka Glaukopisku, Partia Media, 2013), p. 20 etc. Translation mine. perspective, precisely, that we shall examine the question here.

And Maritain's perspective, as we have said, is as simple as it is illuminating. The French philosopher bases his discourse on a very rudimentary observation, or rather differentiation - he manages to notice a fundamental fact: that "the left" and "the right" mean two distinct things. Primarily: the "physiological" or "temperamental" disposition of the subject, with "Left" signifying the general desire to change the status quo in the name of the good - "Right": the desire to conserve things in the name of justice; and secondarily "ideals, energies, and historical formations by which men of these two opposing temperaments are led to assemble together"14. Rational sense is here but a super-structure of the infra-rational sense, with all values that favor change and betterment (at least in intention) of the life of the people before "law and order," values such as freedom, independence, toleration etc. pertaining to the left and tradition, authority, hierarchy - to the right. Consequently, the concrete political schemes aimed at realizing the values of the right should be considered "rightist" and these of the left - "leftist." This is the only manner in which it can be explained. The general fiasco of classifying political doctrines stems from the fact, that political scientists tend to focus on the last stratum of the problem, which can never be understood without reference to the levels of values/ideals, and these, in turn - to the temperamental, physiological dimension that fuels them, and the whole: to how a given person deals with his or her temperament (whether he develops it or represses it etc.). In other words: it is the man that makes left or right. Some ideas, on the surface identical, in different historical circumstances pertained, for example, first to the left and then to the right, as the example of nationalism demonstrates very clearly ${ }^{15}$. Also, one might meditate upon the real meaning of the social state, say, respectively in democratic socialism and national socialism. Fundamentally, history and ideas depend upon the human subject and forgetting this fact is a straight road towards the end of humanities, not only for logical (humanities without the human subject?), but also for this one pragmatic reasons: because it really renders them ineffectual in dealing with reality.

If we examine the problem from this perspective, ascertaining the political orientation of Gilbert Keith Chesterton is far from difficult. I propose to preserve in our proceedings the logical structure that Maritain created and

\footnotetext{
14 Maritain, Letter on Independence, pp. 131-132.

15 Peter Alter, Nationalism, trans. Stuart McKinnon-Evans (London-New York-Melbourne-Auckland: Edward Arnold, 1992), pp. 27-28, 32-33, 3740. I am referring here predominantly to Alter's brilliant differentiation between Risorgimento or liberal nationalism and integral (authoritarian) nationalism.
} 


\section{Philosophy International Journal}

thus begin our analysis from the level of temperament; let us ask: was Chesterton of the left wing - or the right wing temperament? Did he desire change and betterment or law and order? Was he, "by birth," an idealist or a pragmatist?

There is one motive in Chesterton's literary and publicist creation that seems to settle the matter once and for all: his fascination with the revolution and especially - the French Revolution, which he seems to have viewed as a "type" of revolutionary tradition. Gilley noticed it and Oddie noticed it - we are not alone. But really, one wonders how was it possible that some chestertonologists had not noticed it. For "fascination" seems to serve here as a euphemism. It was a life-long, almost religious devotion, that marks the whole course of Chesterton's publicist activity. An entire paper, nay entire monograph could be written on the subject, so we here are going to have to content ourselves with a tragically short and makeshift survey, which - however - might be hoped to suffice to clarify at least the weight of the question and the most general energies at work here. Thus, the revolutionary question enters Chesterton's writings as soon as in his youth, namely: when he was eighteen; as Oddie reports, he wrote a long and emotional poem about the death of Danton effectuated by Robespierre, in which he flamingly declares his sympathies on the side of the murdered cordeliere and against the jacobin ${ }^{16}$. It is, therefore, quite unsurprising that the topic returns, even in quite unpolitical works, such as the famous Orthodoxy (1908), where Chesterton could not refrain from remarking about "the French Revolution that created the peasant wealth of France"17. Or his study of the English literature of the Victorian period (1914), in which book we read, in connection with the problem of the French Revolution, about "the Gospel of Rousseau, glorious truisms that refreshed the souls of the nations" ${ }^{18}$. The fact that such remarks made their way into wholly (at least on the surface - for we are quite aware of the famous "I never discuss anything else except for politics and religion"19) unpolitical works seems to me extremely telling and only proves that for Chesterton the French Revolution was as if a "pivot" of history, a central occurrence, around which history revolved. Yet it is the political books, of course, that serve here as the main sources of data. Thus, for example, in his article from the The Daily News (4 May 1907) cited by Oddie, we find a passage relating to the 1905-07 Revolution in Russia which reads: "It is clear that in some way there is a Revolution of

\footnotetext{
16 Oddie, Chesterton and the Romance of Orthodoxy, pp. 77-78.

17 Gilbert Keith Chesterton, Orthodoxy (United States of America: Popular Classics Publishing, 2012), p. 25.

18 Gilbert Keith Chesterton, The Victorian Age in Literature (New York: Henry Holt and Company, 1914), pp. 19, 22.

19 Lawrence J. Clipper, "Introduction" in ed. Lawrence J. Clipper, The Collected Works of G.K. Chesterton, Vol. 27 (San Francisco: Ignatius Press), p. 24.
}

some kind going on in Russia; and that ought to be enough to make any healthy man happy. Revolution is certainly the divine part of man; 'Behold, I make all things new'"'20. In Irish Impressions (1919), Chesterton openly calls himself "a radical in sympathy with the revolutionary legend"21. In The New Jerusalem (1920), he uses a personification, an image of the French Revolution "walking through the streets of Cairo" in order stress the scope and positive character of the changes it effectuated ${ }^{22}$. Finally, in What I Saw in America (1922) he explicitly expresses his sympathy with the revolutionary heritage in history and urges for its reconciliation with the traditions of Catholicism, which he renders by the means of the symbolic expression of an alliance between "the Red Cap and the Red Cross"23.

Obviously, all of these passages carry important speculative meaning, but what interests us here the most for now is the manner of expression. Let us just examine the manner in which Chesterton talks about the problem: the metaphor of the "gospel," the reference to the Scripture (the Apocalypse, to be exact), a metaphor of "legend" bringing into mind something of the heroic ethos of chivalry and the struggle between good and evil, a personification that endows the French Revolution with (as if) character and reality of a living person, finally: a symbol and a comparison at once, which again placed the revolutionary wars in the context of chivalry - all of these tropes are simply "filled to the brim" with positive emotions and connotations, and point to one thing: the fact that Chesterton simply enjoyed speaking and thinking about the subject; he regarded revolution, any revolution, with an almost aesthetic pleasure that is clearly visible in his writings - and that can be explained solely by the fact of his general "left-winged" temperamental disposition, of this general fondness of change and creation which the left, physiologically taken, fundamentally and simply is. Such enthusiasm towards the revolution as revolution, for the sole purpose of its being revolutionary, is a thing unimaginable in a born conservatist.

It is quite unsurprising that from this "pre-political," emotionalo-moral (so to speak) structure of character there flowed corresponding political ideas, also fitting in the leftwing frame of thinking. "Primary" (if I might say so) political ideas in greater bulk stemming from the thought of Jean Jacques Rousseau, taken by Maritain as the quint-essential

20 Gilbert Keith Chesterton, "The Indispensable Fire," The Daily News (4 May 1907) in: Oddie, Chesterton and the Romance of Orthodoxy, p. 372.

21 Gilbert Keith Chesterton, Irish Impressions (Alcaster: Read Books, 2012), p. 51.

22 Gilbert Keith Chesterton, The New Jerusalem (United States of America: Watchmaker Publishing, 2010), pp. 18-19.

23 Gilbert Keith Chesterton, What I Saw in America (New York: Dodd, Mead \& Company, 1922), p. 197. 


\section{Philosophy International Journal}

philosopher of the political left (and, as Bronisław Baczko demonstrated, in Rousseauism even conservatism is leftist ${ }^{24}$ ). Chesterton had an extensive knowledge of Rousseau - he rarely made it known (for reasons that are in themselves interesting but about which we have no time to speak here), but in an article "A Note on Rousseau" from 1930 issue of G.K.'s Weekly, while feverishly defending Jean-Jacques against the accusation of his being the "father of Bolshevism" (Dean Inge dixit), he calls his a "genious" and openly reveals a connection between Rousseau's thought and his own views - especially Distributism ${ }^{25}$. It is thus unsurprising that Chesterton declared his support for such political ideas of the Swiss philosopher as, predominantly, the general will. The shadows and traces of its presence in Chesterton's thought are scattered in his texts here and there - we have to leave them aside, but one of the clearest declaration upon the subject can be found in a little book Christendom in Dublin he penned in 1932. When walking through the streets of the capital of the Free Irish State, Chesterton sees masses of men, which - he reports - display such a moral and origanizational unity that cannot help to perceive them as, so to speak, one entity, which Chesterton quasi-personifies under the name of "the Mob"; with this "Mob" being endowed with a common will - a General Will, which (as we learn again by the means of metaphorical personification - not the similarity with the case of the Revolution) "walked about the Streets of Dublin for a week" ${ }^{\prime 26}$. And, he adds, the doctrine of General Will is precisely this point as to which "Rousseau was really right when his critics were really wrong" - and not just any other view under the sun, but "the point of democracy," the essence of democratic government ${ }^{27}$.

I understand that old prejudices are difficult to eradicate, and it is more than telling that The Chesterton Review, in the editorial note above "A Note on Rousseau" characterized Chesterton's reference to the Swiss philosopher as "surprising," but one simply cannot ignore a testimony as simple and unambiguous as this.

And from the affirmation of the Rousseauist "voluntarism" there followed another consequence, namely: the affirmation of "contractualism," of the doctrine of the social contract according to which the appearance of the political society is a result of a free act of a group of people, an agreement that binds them together into one collective body. And, well, one of the earliest and most telling remark about the subject can be found in no other book than... Orthodoxy, which we have

24 Bronisław Baczko, Rousseau: Samotność i wspólnota (Warszawa: Państwowe Wydawnictwo Naukowe, 1964), pp. 619-620.

25 Gilbert Keith Chesterton, "A Note on Rousseau," The Chesterton Review, Vol. 19, No. 4 (1993), pp. 453-455.

26 Gilbert Keith Chesterton, Christendom in Dublin (Wrocław: Crossreach Publications, 2017), p. 50.

27 Ibid., p. 52. already cited here; in chapter V, "The Flag of the World," we read: "The eighteenth-century theories of the social contract have been exposed to much clumsy criticism in our time; in so far as they meant that there is at the back of all historic government an idea of content and co-operation, they were demonstrably right" ${ }^{\prime 2}$. So, at least, a partial identification is taking place, with an attack on the "clumsy criticism" (alliteration) adding force to this assertion - and indeed, confirmation can again be sought for literally anywhere. The doctrine finds its symbolical expression, for example, in a beautiful essay "In the Place de la Bastille" from Tremendous Trifles (1909), where Chesterton, while musing upon the most dramatic occurrences connected with that place, tells us suddenly that the French Revolution began with the people realizing that Bastille was but a human construct, that "man made it and thus man could unmake $\mathrm{it}^{29}$. And obviously Bastille is here but a symbol of the ancient regime. It is therefore simply a theory of contractualism poetically phrased: the nature of state is compared to that of the building, so it as well, just like building, even though it is a large and firm structure, is but a human construction, so an effect of a free decision, that can be de-constructed and reconstructed whenever people decide that they want it so. Such and similar motives can, again, be found in a major bulk of Chesterton's works - all we can do here is to signalize the direction of potential further research.

Especially that we have yet another problem to deal with here; a very important one. It is true, then, that Chesterton declared loyalty to some of the political doctrines that can most surely be classified as pertaining to the left wing of politics. However, did he not do so as to some of the political doctrines pertaining to the right wing? Family, tradition, private property - these values are connected decidedly more to the principle of order than that of change; they are as "rightist" as right can be. Obviously Chesterton is well known for being a "defender" (it is, by the way of parenthesis, one of the most irritating chestertonological cliches ever made - we shall return to this later) of these things. Does it not classify him a thinker of the right or, if we accept our conclusions from above, at least "move" him towards the center?

To answer this question, we must return again, for a moment, to our theoretical point of departure. We have already alluded to it pointing to the different meaning of socialism in its democratic or national mutations. Politics, obviously, is a practical affair; and practical affairs, practical perfections of the intellect, as we might say, as we know from Maritain, are not only based on the theoretical assumptions, but display, in themselves, a gradations of the many levels of

28 Chesterton, Orthodoxy, p. 42.

29 Gilbert Keith Chesterton, Tremendous Trifles (Australia: Book Jungle, date of publication missing), p. 34 . 


\section{Philosophy International Journal}

practicality, from the most general principles to the most concrete schemes and techniques of attaining them here and now, where they border with a level of properly moral action which is the reign of the will ${ }^{30}$. We see, then, here a certain hierarchy of ideas, with the more practical being intellectually grounded in the less practical - just like the practical order of knowledge as a whole is grounded in the theoretical order of knowledge. Now, from this clearly follows that when it comes to judging someone's immediate political program, the question that should be asked is not only what one proposes, but also why - what is the ground, the motivation, of his or her proposition. And when the matter is examined from this perspective, the question ceases to be problematic - nay: it also adds force to our argument here, for if Chesterton supported some political institutions that can be associated with the right, he did it solely from the left wing motivations.

Consider, for example, the case of the family. It is obvious that Chesterton did much to "defend" its natural structure against progressive attacks. He did so as early as in the Heretics (1905), where in the essay "On Certain Modern Writers and the Institution of the Family" he defended it from a humanist perspective, as a kind of "microcosm" in which we can realize our full potential as human being and experience the richness and variety of life (in his characteristic style he calls it metaphorically the "romance of the family" ${ }^{31}$ ). He also made securing the being and well-being of the family structure a part of his political program - in the books such as, for example, What's Wrong with the World (1911) or The Superstition of Divorce (1920). But why, let us ask, did he do it? How did he justify his choice? The second book in question provides us here with an excellent answer, for it is in it that we read a most telling passage:

most of us, I fancy, are now agreed that something of that social pressure from below which we call freedom is vital to the health of the State; and this it is which cannot be fully exercised by individuals, but only by groups and traditions. Such groups have been many; there have been monasteries; there may be guilds; but there is only one type among them which all human beings have a spontaneous and omnipresent inspiration to build for themselves; and this type is the family ${ }^{32}$.

In other words: the institution of the family is affirmed and

30 Cf. Jacques Maritain, The Degrees of Knowledge, trans. under the supervision of Gerald B. Phelan (Notre Dame, Indiana: University of Notre Dame Press, 2011), pp. 330-334.

31 Gilbert Keith Chesterton, Heretics (Mineloa, New York: Dover Publications, 2006), pp. 95-96, 101-102.

32 Gilbert Keith Chesterton, The Superstition of Divorce (London: Catholic Way Publishing, 2013), p. 19. supported on the ground that it secures the political (and, accidentally, economic, though it is a matter for another time) liberty of the individual, his or her ability to exercise "a social pressure from below," that is: fulfill the creative role of the citizen in the public affairs, the great process of "painting and repainting" one's state "like a house" 33 (a metaphor used to render the French ideal of citizenship from The Crimes of England [1915]) that results logically from the contractualist position. It thus remains completely within the framework of the "left-winged" political mind (if I might say so).

The same phenomenon we observe in the case of tradition. Once again, it is fully affirmed (Chesterton calls it in "A Note of Rousseau" "communications" that connect nature and culture ${ }^{34}$ ) - what, however, is the principle of this affirmation? The answer to this question can be found in Orthodoxy, in a famous passage, indubitably known to all who took even a superficial interest in Chesterton's writings:

I have never been able to understand where people got the idea that democracy was in some way opposed to tradition. It is obvious that tradition is only democracy extended through time. It is trusting to a consensus of common human voices rather than to some isolated or arbitrary record. The man who quotes some German historian against the tradition of the Catholic Church, for instance, is strictly appealing to aristocracy. [...] Tradition may be defined as an extension of the franchise. Tradition means giving votes to the most obscure of all classes, our ancestors. It is the democracy of the dead. Tradition refuses to submit to the small and arrogant oligarchy of those who merely happen to be walking about. All democrats object to men being disqualified by the accident of birth; tradition objects to their being disqualified by the accident of death. Democracy tells us not to neglect a good man's opinion, even if he is our groom; tradition asks us not to neglect a good man's opinion, even if he is our father. I, at any rate, cannot separate the two ideas of democracy and tradition; it seems evident to me that they are the same idea $^{35}$.

Now, the matter seems quite evident, so only a word of commentary should suffice: it is quite obvious that though both tradition and democracy are affirmed at one blow,

33 Gilbert Keith Chesterton, The Crimes of England (Teddington: The Echo Library, 2006), p. 42.

34 Chesterton, “A Note on Rousseau," p. 455.

35 Chesterton, Orthodoxy, p. 29. 


\section{Philosophy International Journal}

it is tradition that is being affirmed because it is a form of democracy, and not democracy because it is a form of tradition. The hierarchy of values is crystal clear, and if we remember that Chesterton, as we have demonstrated, believed in the Rousseauist concept of democracy, the leftwinged character of this affirmation is beyond doubt.

The case is similar, let us add, with another one of the most "rightist" points of Chesterton's doctrine - his medievalism, so extensively elaborated upon in the famous work by Przemysław Mroczkowski, which might be (with some stretching perhaps, but it is "functional") into his general traditionalism. Simply speaking - Chesterton was a medievalist, true. But he was one for the simple reason that he considered Middle Ages quite democratic - or at least pre-democratic. We find innumerable instances of this in The new Jerusalem, of which here I will include only one: "It is indeed a long exploded fallacy to regard medievalism as identical with feudalism. There were countless democratic institutions, such as the guilds; sometimes as many as twenty guilds in one small town" ${ }^{16}$. As we can see: it is the same logical structure - medievalism is to be supported because middle ages were democratic, and not vice versa. The matter definitely would require more elaboration, nay: maybe a separate monograph. Fascinating as it would be, we cannot follow the unfolding of this discourse here - it is an effort for another time. All that can be hoped for for now is that our outline, or signalizing, will bear fruit in its own time and place.

Lastly, the matter of property; it is true, of course, that a large distribution of private property was the cornerstone of the Distributist program. Superficially, this could be taken for a sign of affinity with the right-wing economic doctrines, especially capitalism, but again, if the motivation is taken into account, the picture changes dramatically. Because in capitalism private ownership is seen primarily as a tool of constant accumulation and reinvestment, in simper terms: of individual gain ${ }^{37}$. Hence the idea that it is fundamentally at odd with the communal bond. For Chesterton - on the contrary: private property, if well-distributed, becomes a limit upon individual gain. In The Outline of Sanity (1925) he expresses this concept with a famous symbolical metaphor of an arch: just like arch is built by "by combining separate stones of a particular shape in a particular way, we can ensure that their very tendency to fall shall prevent them from falling," so "in a healthy society the moral pressure of different private properties acts in exactly the same way"38.

36 Chesterton, The New Jerusalem, p. 151.

37 Ellen Meiksins Wood, The Origin of Capitalism (London-New York: Verso, 2017), pp. 7, 107-108 etc.

38 Gilbert Keith Chesterton, The Outline of Sanity (Rookhope: Aziloth Books, 2011), pp. 11-12.
Proprietary system (to use this phrase of Belloc's from The Servile State) creates a certain moral and economic balance that secures the well being of the community against the excesses of individual adventuring. In other words: it is prosocial, not individualistic - it equalizes, not divides. It is, therefore, not by accident that Chesterton hoped, in the same Outline..., but not only, for a renewal of communal traditions, of the centers of local and traditional culture, resembling "dances, embroideries, handicrafts" of the distributist peasant communities of the past ${ }^{39}$.

And of course, let us add, property, for Chesterton, has one more interesting feature: it is an "art of democracy"40 the condition of liberty ${ }^{41}$. That is the second reason it should be affirmed and, if necessary, defended. In other words: its value resides in the fact that it as well contributes to the ideal of citizenship and political liberty. This motive, let us add, runs through all of the Chesterton's writings. In this case, just like in the case of Chesterton's medievalism (and rather everything else in this text) we have to content ourselves with the role of a "signaler"; we signalize the direction so others might follow it.

Again, then, in this case as in the two previous ones what we are dealing with is a typically left-winged idealism: a desire for goodness, well-being, and even - change (as far as civil liberty is for Chesterton an ability to change the state and property - a necessary tool of maintaining liberty). Even the most "rightist" of Chesterton's views appear, under closer scrutiny, as far from the right as far can be. The similarities prevail only on the surface - when the matter is examined with more depth, they vanish - and it is, indeed, almost stupefying how effortless it is to do away with them if the question is treated with enough attention. Indeed, one might wonder how could it be possible to view the case in any other light - how, for example, could Christopher Hollis in his book The Mind of Chesterton use so much energy only to make Chesterton, to use here Gilley's expression, into "a kind of fascist."42 Or how all the instances of the same procedure that we have already outlined here were possible. When Chesterton said that his political sympathies lied rather with the socialists than capitalists (thus with the left than with the right) ${ }^{43}$ it was not an accident, a joke or just a meaningless phrase thrown off in a hurry by a "court jester" of the Edwardian England. It was simply an assessment of

39 Ibid., p. 69, Gilbert Keith Chesterton, Avowals and Denials (New York: Dodd, Mead \& Company, 1935), p. 70.

40 Gilbert Keith Chesterton, What's Wrong with the World (Mineloa, New York: Dover Publications, 2007), p. 35.

41 Chesterton, Irish Impressions, p. 48.

42 Christopher Hollis, The Mind of Chesterton (London-Sydney-Toronto: Hollis \& Carter, 1970), pp. 15-16, 19 etc.

43 Chesterton, The New Jerusalem, p. 10. 


\section{Philosophy International Journal}

a fact. And let me be well-understood: I am not denying, by any means, the differences that occur between Chesterton's thought and socialism, especially Marxist socialism. The most obvious one can be traced on the basis of what we have said here - it is the question of history, or rather of the interpretation of the past our European civilization. Judging from Chesterton's attitude towards Europe's peasant societies and the heritage of the middle ages, he quite certainly regarded the Marxist concept of society being based solely upon class-struggle and conflict like Arthur J. Penty in his A Guildsman's Interpretation of History (1920): an absurd ${ }^{44}$. His vision of the social change was different, with it having its principle not outside, but inside the civilization of the "ever-changing West" ${ }^{45}$. There is the tremendous difference as to the concept of man (Chesterton was emphatically not a materialist). It is all true. Yet it is also quite obvious that both light and right wing of the political scene constitute certain spectra: they include many different options and nuances. It simply means that Chesterton's "leftism" was much different than the "leftism" of Marx or Shaw. Indeed - it was very, very original, and could enrich not only chestertonological, but generally political studies as well with supremely interesting data. But the fact that is was $a$ form of "leftism" seems to me quite undeniable - and one of the most fundamental reasons of the general failure to notice it is a terrible habit, which I have already mentioned in passing, of viewing Chesterton chiefly as "the defender": defender of reason, faith, family or what not. Thus: negatively. Negative perspective is always scholarly deficient. The only thing I would thus urge here to do is to abandon it as promptly as possible - and begin to look primarily at what Chesterton said, no against what. Only this will allow his ideas to manifest themselves with full force and, to quote Mr. Huntbach once again, "explain" their relevance for modern times. And it is not just an ordinary relevance. Indubitably, such an interpretation of Chesterton's writings would prove extremely difficult; but also - extremely fruitful. Before one can interpret, however, one has to listen. And perhaps the highest claim this paper, with all said and done, can have is simply to invite its readers precisely to this: that they suspend their prejudices, find a moment of free time, and give an ear for a while or two to a very interesting interlocutor: one Gilbert Keith Chesterton.

\section{References}

1. Aleman Richard (2015) The Hound of Distributism. Charlotte: ACS Books.

2. Alter Peter (1992) Nationalism. Stuart McKinnon-Evans (Trans.). London.

\footnotetext{
44 Arthur J. Penty, A Guildsman's Interpretation of History (London: George Allen \& Unwin, 1923), pp. 9-10.

45 Chesterton, The New Jerusalem, p. 16.
}

3. Baczko Bronisław (1964) Rousseau: Samotność i wspólnota. Warszawa: Państwowe Wydawnictwo Naukowe.

4. Bartyzel Jacek (2016) Prawica-nacjonalizmmonarchizm. Warszawa: Wydawnictwo Von Borowiecky.

5. Chesterton GK (1914) The Victorian Age in Literature. Henry Holt and Company.

6. Chesterton GK (1922) What I Saw in America. Dodd, Mead \& Company.

7. Chesterton GK (1935) Avowals and Denials. Dodd, Mead \& Company.

8. Chesterton GK (1993) The Chesterton Review. A Note on Rousseau. Philosophy Documentation Center 19(4): 453-455.

9. Chesterton GK (2006) Heretics. Dover Publications.

10. Chesterton GK (2006) The Crimes of England. Teddington: The Echo Library.

11. Chesterton GK (2007) What's Wrong with the World. Dover Publications.

12. Chesterton GK (2010) The New Jerusalem. Watchmaker Publishing.

13. Chesterton GK (2011) The Outline of Sanity. Aziloth Books.

14. Chesterton GK (2012) Orthodoxy. Popular Classics Publishing.

15. Chesterton GK (2012) Irish Impressions. Read Books.

16. Chesterton GK (2013) The Superstition of Divorce. Catholic Way Publishing.

17. Chesterton GK (2017) Christendom in Dublin. Crossreach Publications.

18. Chodakiewicz MJ (2013) O prawicy i lewicy. Partia Media.

19. Chesterton GK (2007) Tremendous Trifles. Book Jungle.

20. Clipper LJ (1986) Introduction. In: The Collected Works of G.K. Chesterton. Lawrence J Clipper (Ed) 27th (Vol.). Ignatius Press, pp: 21-31.

21. Coplestone Frederick (1994) A History of Philosophy. 6th (Vol.). Image Books.

22. Hollis Christopher (1970) The Mind of Chesterton. Hollis \& Carter, pp: 291-293. 
23. Huntbach Matthew (1992) The Chesterton Review. Chesterton and the Political Left. Philosophy Documentation Center 18(3): 464-465.

24. Maj Przemysław (2018) Lewicowość, centrowośc i prawicowość w nauce o polityce. Wydawnictwo Uniwersytetu Rzeszowskiego.

25. Maritain Jacques (1944) Science and Wisdom. London: Lowe and Brydon Printers Limited.

26. Maritain Jacques (2011) The Degrees of Knowledge. Gerald B Phelan (Transl.). Notre Dame, University of Notre Dame Press.

27. Maritain Jacques (2012) Letter on Independence. Otto Bird (Trans.). In: Otto Bird (Ed.), The Collected Works of Jacques Maritain. $11^{\text {th }}$ (Vol.), University of Notre Dame Press, pp: 119-139.

28. Mroczkowski Przemysław (1974) The Medievalism of Gilbert Keith Chesterton a critical enquiry, $1^{\text {st }}$ (Vol.). Państwowe Wydawn.

29. Mroczkowski Przemysław (1976) The Medievalism of Gilbert Keith Chesterton: a critical enquiry, 2nd (Vol). Zakład Narodowy imienia Ossolińskich.

30. Oddie William (2010) Chesterton and the Romance of Orthodoxy. Oxford University Press.

31. Oddie William (2010) The Holiness of Gilbert Keith Chesterton. Gracewing.

32. Penty Arthur J (1923) A Guildsman's Interpretation of History. George Allen \& Unwin.

33. Jean Jacques Rousseau (1993) The Social Contract and the Discourses. Everyman's Library.

34. Woods Ellen Meiksins (2017) The Origin of Capitalism. Verso. 